\title{
Vegetation succession in extensive abandoned tall-trunk cherry orchards: a case study on Kaňk Mountain near Kutná Hora (Czech Republic)
}

\author{
Markéta Šantrůčková ${ }^{1, *}$ (1) , Jiří Dostálek ${ }^{1}$ \& \& Tomáš Frantík ${ }^{2}$ (1)
}

Key words: secondary succession, land use abandonment, extensive tall-trunk orchards, arable soil, medieval ore extraction.

Ključne besede: sekundarna sukcesija, opuščanje rabe tal, ekstenzivni visokodebelni sadovnjaki, obdelana tla, srednjeveško izkoriščanje rude.

Received: 23. 5. 2019

Revision received: 15 . 10. 2019

Accepted: 30. 10. 2019

\begin{abstract}
Extensive tall-trunk orchards, an important element of the central European landscape since the Middle Ages, conserve potential for the future regarding their biodiversity, land use policy and agricultural value. For these reasons, extensive tall-trunk orchards are interesting with regard to nature conservation. Once the management of these low-productivity vegetation sites ceases, the habitat is threatened by successive overgrowth by shrub vegetation. Taking abandoned tall-trunk cherry orchards with dry/mesophilous grassland undergrowth in the locality of Kaňk as an example, the degree of colonization of orchards by woody species and differences in the structure of vegetation cover in different periods after abandonment were monitored. The results showed that the cover of cherry trees in orchards abandoned before 1990 was approximately $30 \%$ lower than in orchards abandoned after 2000 . The cover of the herb layer in orchards abandoned before 1990 was approximately $60 \%$ lower than in orchards abandoned after 2000. The species diversity of orchards abandoned before 1990 was statistically significantly lower than that of orchards abandoned after 2000. The total cover of all species in habitat in areas of medieval ore extraction was approximately $50 \%$ lower than that in land originally used for farming.
\end{abstract}

\begin{abstract}
Izvleček
Ekstenzivni visokodebelni sadovnjaki že od srednjega veka predstavljajo pomemben element srednjeevropske krajine in potencial za prihodnost zaradi svoje biotske pestrosti, rabe tal in kmetijske vrednosti. Zato so visokodebelni sadovnjaki pomembni za naravovarstvo, saj opuščanje gospodarjenja s temi nizko produktivnimi rastišči pomeni ogroženost habitata zaradi zaraščanja z grmiščno vegetacijo. Kot objekt spremljanja stopnje zaraščanja z lesnatimi vrstami in sprememb v strukturi vegetacije v različnih obdobjih po opustitivi, smo izbrali visokodebelne češnjeve sadovnjake s suhimi/mezofilnimi travišči v podrasti na območju Kaňk. Rezultati kažejo, da je pokrovnost češnjevih dreves v sadovnjakih, opuščenih pred letom 1990, manjša za 30\% v primerjavi s sadovnjaki, opuščenimi po letu 2000. Pokrovnost zeliščne plasti v sadovnjakih, opuščenih pred 1990 je bila 60\% manjša, kot v sadovnjakih, opuščenih pred letom 2000. Vrstna pestrost sadovnjakov, opuščenih pred letom 1990 je bila statistično značilno nižja kot pri sadovnjakih, opuščenih pred letom 2000. Skupna pokrovnost vseh vrst v habitatih, kjer so v srednjem veku kopali rudo, je bila približno $50 \%$ manjša kot na območjih, ki so jih izvorno uporabljali za kmetovanje.
\end{abstract}

\footnotetext{
1 Silva Tarouca Research Institute for Landscape and Ornamental Gardening, Květnové náměstí 391, 25243 Průhonice, Czech Republic.

2 Institute of Botany, Academy of Sciences of the Czech Republic, CZ-252 43 Průhonice, Czech Republic. E-mail: frantik@ibot.cas.cz

* Corresponding author: E-mail: santruckova@vukoz.cz
} 


\section{Introduction}

Traditional cultural landscapes managed under less intensive agriculture and forestry exhibit a high diversity of habitats and therefore high biodiversity (McCollin et al. 2000, Agnoletti 2014). Past land cover may persist as a memory or legacy for a very long time in ecosystems, potentially influencing ecosystem responses, productivity and biodiversity. On the other hand, land use / land cover changes ultimately affect biodiversity from a long-term perspective (Heubes et al. 2011, Bürgi et al. 2017). Vačkáŕ et al. (2012) suggested that high biodiversity at both species and landscape heterogeneity levels are correlated with the intermediate human impact in the Czech Republic.

In recent decades, in the context of socio-economic changes linked to the mechanization and modernization of agricultural production technology, there has been both intensification and abandonment of formerly more extensively used less fertile farmland (Antrop 2005). Abandoned areas are currently at different stages of succession. Considerable attention is given to vegetation succession in abandoned farmland in terms of its importance for forest production, nature conservation and landscape diversity (e.g., Benjamin et al. 2005, Benayas et al. 2007, Verburg \& Overmars 2009, Ustaoglu \& Collier 2018). Recent studies have mainly investigated vegetation dynamics in abandoned arable land or meadows (e.g., Jensen et al. 2001, Cramer \& Hobbs 2007, Hobbs 2012). In the Czech Republic, long-term research in abandoned fields in the Protected Landscape Area of Český kras has been carried out (see Osbornová et al. 1990). However, little attention has been paid to studying vegetation changes in tall-trunk orchards after abandonment (e.g., Debussche et al. 1982, Milton et al. 1997).

Extensive tall-trunk orchards are one of the traditional land cover types and landscape structures that have seriously decreased because of agricultural development during previous periods. Orchards on slopes those are less suitable for intensive agricultural management have been a part of the Central European cultural landscape since the Middle Ages. The orchard grounds are usually covered by grasslands that are used for sheep or goat grazing. Plots of orchards or fruit trees can be mixed with small fields (Lange 1993, Schultze \& Gertsberger 1993, Maděra et al. 2014, Špulerová et al. 2015, Forejt et al. 2017). Tall-trunk orchards are important ecological and cultural landscape features. Although these orchards are human-introduced land cover, they fulfil several ecological services (Kay et al. 2018, Špulerová et al. 2018) and conserve higher potential for the future regarding their biodiversity, land use policy and agricultural value (Janeček et al. 2019).
For example, a combination of extensive planting of tall-trunk orchards and semi-dry grasslands forms a biotope to which a number of plant and animal species are found that are rare in the other habitats (e.g., Blab 1993, Reck 1993, Duchoslav 2009, Horák \& Šafárová 2010). For breeding birds, both extensive tall-trunk orchards and orchards in the early stage of abandonment are important habitats. On the other hand, intensively managed shorttrunk orchards have significantly lower ecological value (Kajtoch 2017). Horák et al. (2013) compared orchards with other land cover types (grasslands and woods) and proved that the presence of orchards is significant for butterflies, land snails, plants, and birds. For these reasons, orchards are interesting for nature conservation. However, when the management of these habitats ceases, they are threatened by successive overgrowth by shrub vegetation, and they gradually disappear.

Surprisingly, orchards are a relatively dynamic land use category. Generally, we can assume that their area slightly increased during the $19^{\text {th }}$ and $20^{\text {th }}$ centuries but decreased markedly from the 1990s to the present in the Czech Republic (Bič́k et al. 2010). Several sources are available and are often used for studying land cover changes in the central European landscape. Old medium- and large-scale maps are available from the late $18^{\text {th }}$ to the late $19^{\text {th }}$ centuries, and aerial photographs are available for the $20^{\text {th }}$ century that allow us to study not only the extent but also the quality of identified land cover patches (Skaloš et al. 2011, Šantrůčková et al. 2015, Forejt et al. 2017).

The aim of this work is to describe the degree of colonization of orchards by woody species and differences in the composition of vegetation cover in different periods after abandonment based on the example of tall-trunk cherry orchards with dry grassland undergrowth in the locality of Kaňk near Kutná Hora.

\section{Methods}

\section{Study area}

The study was performed on Kaňk Mountain, situated approximately $2 \mathrm{~km}$ northeast of the city of Kutná Hora (Czech Republic). Kutná Hora region was famous by its orchards in the 20th century. Orchards on the Kank Mountain are interested among the others because some of them were founded on the plots of the medieval ore extraction. Extensive abandoned tall-trunk orchards are mainly located on southward-exposed slopes at approximately $300 \mathrm{~m}$ a.s.l. (Figure 1). The geological bedrock of Kaňk Mountain is formed by Palaeozoic or Precambrian rocks (gneiss, micacites, migmatites, and migmatitised orthogneiss) and partly by Mesozoic rocks (marlstones 
and siltstones). The Quaternary cover is composed of sands and gravels; there are also diluvial sediments on Kaňk Mountain slopes and on the foothills. The soils are categorized as brown earth (Tomášek 2000). The main metal-bearing minerals are native $\mathrm{Ag}$ and high-quality ores with minerals such as tetrahedrite, freibergite, argentite, proustite, pyrargyrite, galenite, and sulphides of $\mathrm{Fe}$, $\mathrm{Zn}, \mathrm{As}, \mathrm{Cu}, \mathrm{Pb}$. Because of long-term mining and smelting activities, the soils of the model area are strongly contaminated, mainly by As and Cd, and a high concentration of $\mathrm{Hg}$ may or may not be connected with the mining process (Horák \& Hejcman 2013, 2016a, 2016b).

The mean annual air temperature in the area is $9{ }^{\circ} \mathrm{C}$, and the mean annual precipitation rate is $584 \mathrm{~mm}$. The mean temperature in January ranges from -2 to $-3{ }^{\circ} \mathrm{C}$, and the total precipitation amount during the winter period ranges between 200 and $300 \mathrm{~mm}$. The mean temperature in June is $18-19^{\circ} \mathrm{C}$, and the total precipitation during the growing season ranges between 350 and $400 \mathrm{~mm}$ (Quitt 1971).

According to the map of potential natural vegetation (Mikyška 1968, 1972, Neuhäuslová et al. 2001), the natural vegetation in most of the area would consist of oak-hornbeam and lime-oak woodlands (Carpinion Issler 1931), especially oak-hornbeam woodland with Melampyrum nemorosum (ass. Melampyro nemorosi-Carpinetum Passarge 1962).

Cherry orchards were planted in former arable soil and at the sites of medieval ore extraction, which took place mainly in the period from the 13th to the 16th centuries. The undergrowth of orchards is formed by grassland communities that are classifiable at the boundary of mesic Arrhenatherum meadows (Arrhenatherion elatioris Luquet 1926) and dry grassland (Bromion erecti Koch 1926). In dry habitats, the communities are formed by characteristic species such as Brachypodium pinnatum, Bromus erectus, Festuca rupicola, Salvia pratensis, Eryngium campestre, Scabiosa ochroleuca, Onobrychys viciifolia, Cirsium acaule, rarely occur Stipa capillata, Anthericum ramosum, Bothriochloa ischaemum or Elytrigia intermedia. The presence of critically endangered Stachys germanica is of particular note.

The gradual abandonment of orchard undergrowth management (mostly moving) is associated with overgrowth by woody species, especially by Crateagus sp., Cornus sanguinea, Rosa sp., Ligustrum vulgare, Cornus mas and Prunus mahaleb.

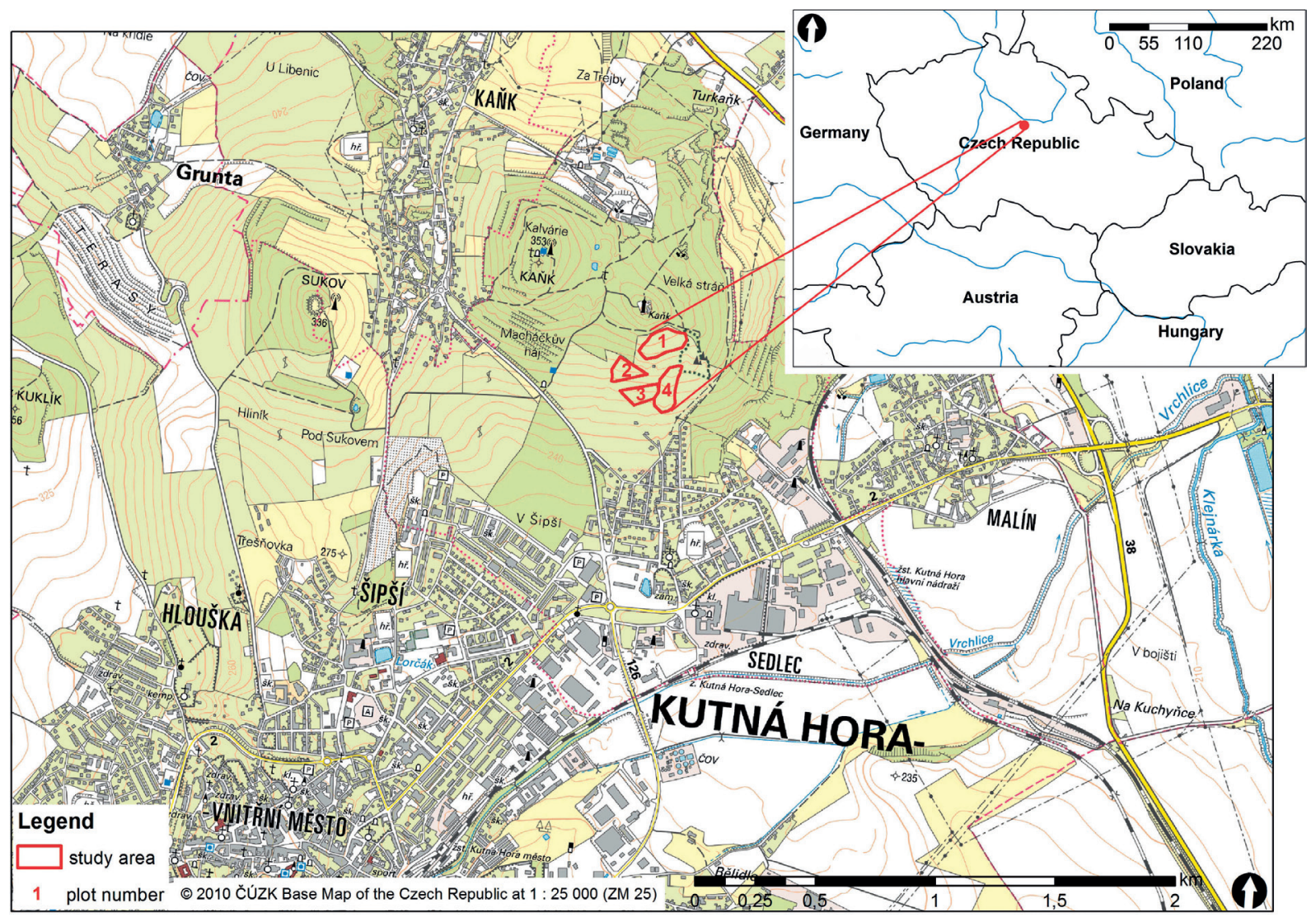

Figure 1: The study area.

Slika 1: Preučevano območje. 


\section{Land cover analysis}

Old maps and aerial photographs were used for analysing land cover and orchard changes over the past 250 years. The available old maps include first military maps (1763-1783, approximately $1: 28800)$, stable cadastral maps $(1838,1: 2880)$, second military maps (1842$1852,1: 28800)$, and third military maps (1874-1880, $1: 25000)$. The oldest aerial photographs are available from the 1930s. The whole area of former Czechoslovakia was photographed regularly every 10 years from the early 1950s onward and more often beginning in the 1990s. We used the 3 oldest aerial photographs of the model area $(1938,1947,1954)$ and then aerial photographs taken at approximately 10-year intervals (i.e., $1963,1972,1983,1993,2004,2013,2018)$ to study land cover and orchard changes.

The land cover categories distinguished in the study area include arable land (ploughed fields), permanent grassland (meadow or pasture), regular orchards (extensive tall-trunk orchards with regular management), and abandoned orchards (tall-trunk orchards where management is irregular or absent). Because the main aim of the study was to examine plant succession in abandoned orchards, we distinguished three phases of orchard abandonment: stage 1 - beginning of spontaneous overgrowth by woody plants, occasional cherry harvesting, regular orchard raster still clear; stage 2 - continuous spontaneous overgrowth by woody plants, regular orchard raster less visible; stage 3 - spontaneous woody plants prevail, no regular raster (Table 1). Succession in some plots progressed quickly, so the phases of orchard abandonment did not flow smoothly from 1 to 3 . The GIS software ArcGIS 10.6.1 was used for data processing.

Table 1: Land cover in old maps and aerial photographs.

Tabela 1: Prostorski podatki na starih kartah in aeroposnetkih.

\section{Data collection and analysis}

A system of plots of $10 \mathrm{~m} \times 10 \mathrm{~m}$ in size was used to sample vegetation data. In July 2010, we examined tall-trunk cherry orchards planted in arable soil at the following sites characterized by different lengths of abandonment: (1) area abandoned after the year 2000 - 5 plots; (2) area abandoned in the period of 1990-2000 - 5 plots; and (3) area abandoned before the year $1990-5$ plots. In addition, 5 plots were examined in a cherry orchard planted at a site influenced by medieval ore extraction and abandoned before 1990 (Table 1). A $3 \times 3$ grid was used to divide each plot into 9 smaller subplots. In each subplot, the percentage of vegetation cover of all species and each individual species, including the cherry plantation, was estimated in mid-July (top of the growing season). In this way, a more precise estimate of cover for each species was obtained for the entire plot, including the mean value and standard deviation. The Shannon-Wiener index of species diversity (Pielou 1966) was calculated for every plot. All cover values and diversity data were evaluated using the program Statistica v. 9.0 (StatSoft Inc. 2009). Differences between different stages of abandonment were tested using ANOVA and Tukey's test or the Kruskal-Wallis test. To reveal the main gradients in vegetation samples, unimodal-based ordinations using CANOCO (Ter Braak \& Šmilauer 2012) were employed.

The nomenclature of vascular plants follows Kubát et al. (2002).

\section{Results and discussion}

\section{Vegetation changes in abandoned orchards established on farmland}

Results of the changes in basic vegetation characteristics during succession in the studied cherry orchards established on arable land are presented in Table 2 and

\begin{tabular}{|c|c|c|c|c|c|c|c|c|c|c|c|c|c|c|}
\hline $\begin{array}{l}\text { Plot } \\
\text { No. }\end{array}$ & $\begin{array}{l}1763- \\
1783\end{array}$ & 1838 & $\begin{array}{l}1842- \\
1852\end{array}$ & $\begin{array}{l}1874- \\
1880\end{array}$ & 1938 & 1947 & 1954 & 1963 & 1972 & 1983 & 1993 & 2004 & 2013 & 2018 \\
\hline 1 & $\begin{array}{c}\text { arable } \\
\text { land }\end{array}$ & $\begin{array}{c}\text { arable } \\
\text { land }\end{array}$ & $\begin{array}{l}\text { arable } \\
\text { land }\end{array}$ & $\begin{array}{l}\text { arable } \\
\text { land }\end{array}$ & $\begin{array}{l}\text { regular } \\
\text { orchard }\end{array}$ & $\begin{array}{l}\text { regular } \\
\text { orchard }\end{array}$ & & & $\begin{array}{l}\text { regular } \\
\text { orchard }\end{array}$ & $\begin{array}{l}\text { regular } \\
\text { orchard }\end{array}$ & $\begin{array}{l}\text { abandoned } \\
\text { orchard: } \\
\text { stage } 1\end{array}$ & $\begin{array}{l}\text { abandoned } \\
\text { orchard: } \\
\text { stage } 1\end{array}$ & $\begin{array}{l}\text { abandoned } \\
\text { orchard: } \\
\text { stage } 3\end{array}$ & $\begin{array}{c}\text { abandoned } \\
\text { orchard: } \\
\text { stage } 3\end{array}$ \\
\hline 2 & $\begin{array}{l}\text { arable } \\
\text { land }\end{array}$ & $\begin{array}{l}\text { arable } \\
\text { land }\end{array}$ & $\begin{array}{l}\text { arable } \\
\text { land }\end{array}$ & $\begin{array}{l}\text { arable } \\
\text { land }\end{array}$ & $\begin{array}{l}\text { arable } \\
\text { land }\end{array}$ & $\begin{array}{l}\text { arable } \\
\text { land }\end{array}$ & $\begin{array}{l}\text { regular } \\
\text { orchard }\end{array}$ & & $\begin{array}{l}\text { regular } \\
\text { orchard }\end{array}$ & & $\begin{array}{l}\text { ular } \\
\text { hard }\end{array}$ & $\begin{array}{c}\text { abandoned } \\
\text { orchard: } \\
\text { stage } 1\end{array}$ & $\begin{array}{l}\text { abandoned } \\
\text { orchard: } \\
\text { stage } 2\end{array}$ & $\begin{array}{r}\text { aban } \\
\text { orc } \\
\text { sta }\end{array}$ \\
\hline 3 & $\begin{array}{l}\text { arable } \\
\text { land }\end{array}$ & $\begin{array}{l}\text { arable } \\
\text { land }\end{array}$ & $\begin{array}{l}\text { arable } \\
\text { land }\end{array}$ & $\begin{array}{l}\text { arable } \\
\text { land }\end{array}$ & $\begin{array}{l}\text { arable } \\
\text { land }\end{array}$ & $\begin{array}{l}\text { arable } \\
\text { land }\end{array}$ & $\begin{array}{l}\text { arable } \\
\text { land }\end{array}$ & $\begin{array}{l}\text { arable } \\
\text { land }\end{array}$ & $\begin{array}{l}\text { regular } \\
\text { orchard }\end{array}$ & $\begin{array}{l}\text { regular } \\
\text { orchard }\end{array}$ & & & $\begin{array}{l}\text { abandoned } \\
\text { orchard: } \\
\text { stage } 1\end{array}$ & $\begin{array}{c}\text { abandoned } \\
\text { orchard: } \\
\text { stage } 1\end{array}$ \\
\hline 4 & $\begin{array}{l}\text { arable } \\
\text { land }\end{array}$ & $\begin{array}{l}\text { grass- } \\
\text { land }\end{array}$ & $\begin{array}{l}\text { grass- } \\
\text { land }\end{array}$ & $\begin{array}{l}\text { grass- } \\
\text { land }\end{array}$ & $\begin{array}{l}\text { regular } \\
\text { orchard }\end{array}$ & $\begin{array}{l}\text { regular } \\
\text { orchard }\end{array}$ & $\begin{array}{l}\text { regular } \\
\text { orchard }\end{array}$ & $\begin{array}{l}\text { regular } \\
\text { orchard }\end{array}$ & $\begin{array}{l}\text { regular } \\
\text { orchard }\end{array}$ & $\begin{array}{l}\text { regular } \\
\text { orchard }\end{array}$ & $\begin{array}{l}\text { abandoned } \\
\text { orchard: } \\
\text { stage } 1\end{array}$ & $\begin{array}{l}\text { abandoned } \\
\text { orchard: } \\
\text { stage } 1\end{array}$ & $\begin{array}{l}\text { abandoned } \\
\text { orchard: } \\
\text { stage } 3\end{array}$ & $\begin{array}{c}\text { abandoned } \\
\text { orchard: } \\
\text { stage } 3\end{array}$ \\
\hline
\end{tabular}




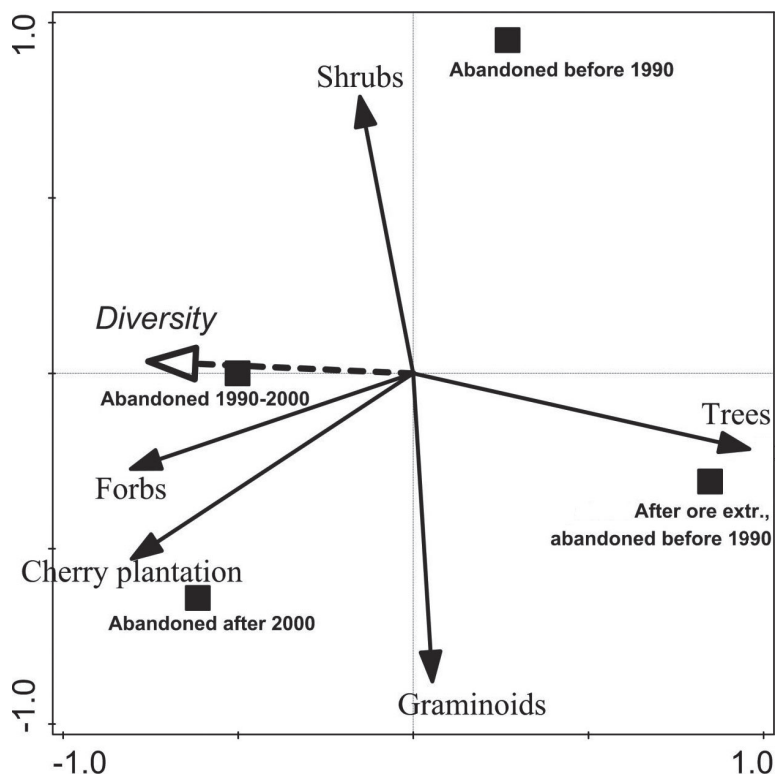

Figure 2: Indirect PCA gradient analysis of vegetation characteristics (the first two axes capture $84 \%$ of data variability) in relation to the length of abandonment and type of habitat. The length of abandonment and type of habitat are indicated with black squares

Slika 2: Indirektna PCA gradientna analiza vegetacijskih značilnosti (prvi dve osi pojasnjujeta $84 \%$ variabilnosti) v odnosu do časa od opustitve rabe in vrsto habitata. Obdobje od opustitve gospodarjenja in vrsta habitata sta prikazana s črnimi kvadrati.
Figure 2. During the study period, the cover of cherry plantations was considerably decreasing, which was caused (in addition to the natural ageing of adult trees) by gradually increasing competitive pressure from growing woody species and by their increasing representation in the overall cover. This situation was also demonstrated by the results of indirect gradient analysis (Figure 2). In connection with the growing woody plant stands, the height and cover of the herb layer, especially forbs, was continuously decreasing considerably. Graminoids were also more abundant in the later period of succession on the area of medieval ore extraction.

The relations of specific plant species (for the list of species, see the Appendix) to the individual studied succession stages were shown by indirect gradient analysis (Figure 3). Areas abandoned after the year 2000 (Figure 4a) and in the period of 1990-2000 (Figure 4b) were associated with the presence of herbs that formed original mown grassland, especially Agrostis sp., Arrhenatherum elatius, Festuca rubra, Galium spurium, Lathyrus pratensis, Lotus corniculatus, Trifolium medium and Taraxacum officinale. This situation can be explained by a considerable proportion of original mown grasslands. In later period of succession, Calamagrostis epigejos prevailed. Brachypodium pinnatum, which belongs to the expansive tall grasses colonizing abandoned habitats of former dry grassland

Table 2: Differences in vegetation variables between individual stages of succession after abandonment of extensive tall-trunk cherry orchards established on arable soil and comparison of vegetation of abandoned extensive tall-trunk cherry orchards established on arable soil and on the habitat after medieval ore extraction.

Tabela 2: Razlike med vegetacijskimi spremenljivkami med posameznimi sukcesijskimi stadiji po opustitvi ekstenzivnih visokodebelnih češnjevih sadovnjakov na obdelanih tleh in primerjava vegetacije opuščenih sadovnjakov, zasajenih na obdelanih tleh $s$ tistimi na jalovini srednjeveških rudnikov.

\begin{tabular}{|c|c|c|c|c|c|}
\hline \multirow[t]{2}{*}{ Characteristic } & \multicolumn{5}{|c|}{ Abandonment period } \\
\hline & $\begin{array}{c}\text { after } \mathbf{2 0 0 0} \\
\text { established on } \\
\text { arable soil } \\
\end{array}$ & $\begin{array}{l}\text { 1990-2000 } \\
\text { established on } \\
\text { arable soil }\end{array}$ & $\begin{array}{l}\text { established on } \\
\text { arable soil }\end{array}$ & $\begin{array}{l}\text { b e f ore } 1990 \\
\text { established in the area } \\
\text { of medieval ore extraction }\end{array}$ & significance \\
\hline Species diversity & $3.74^{\mathrm{a}}$ & $4.31^{\mathrm{a}}$ & $3.26^{\mathrm{b}}$ & 3.06 & n.s. \\
\hline $\begin{array}{l}\text { Vegetation cover - } \\
\text { sum of all species cover [\%] }\end{array}$ & $155^{\mathrm{a}}$ & $174^{\mathrm{a}}$ & $114^{\mathrm{b}}$ & 161 & $* *$ \\
\hline $\begin{array}{l}\text { Woody species cover - } \\
\text { sum of all woody plants cover [\%] }\end{array}$ & $27^{b}$ & $65^{\mathrm{a}}$ & $76^{\mathrm{a}}$ & 72 & n.s. \\
\hline Proportion of woody species cover [\%] & $17^{\mathrm{c}}$ & $37^{\mathrm{b}}$ & $67^{\mathrm{a}}$ & 45 & ** \\
\hline Cover of cherry plantations [\%] & $34^{\mathrm{a}}$ & $22^{\mathrm{ab}}$ & $5^{\mathrm{b}}$ & 5 & n.s. \\
\hline $\begin{array}{l}\text { Shrub species cover - } \\
\text { sum of all shrub species cover [\%] }\end{array}$ & $26^{\mathrm{b}}$ & $63^{\mathrm{a}}$ & $72^{\mathrm{a}}$ & 38 & * \\
\hline Proportion of shrub species cover [\%] & $17^{\mathrm{c}}$ & $36^{\mathrm{b}}$ & $63^{\mathrm{a}}$ & 25 & ** \\
\hline Height of shrub layer $[\mathrm{m}]$ & $3.3^{\mathrm{c}}$ & $4.9^{\mathrm{b}}$ & $5.8^{\mathrm{a}}$ & 6.4 & n.s. \\
\hline Height of herb layer [m] & $0.88^{\mathrm{a}}$ & $0.76^{\mathrm{a}}$ & $0.52^{\mathrm{b}}$ & 0.82 & n.s. \\
\hline Cover of herb layer $[\%]$ & $83^{\mathrm{a}}$ & $47^{\mathrm{b}}$ & $23^{c}$ & 57 & $* *$ \\
\hline
\end{tabular}

Legend: Different letters indicate statistically significant difference on $\mathrm{p}=0.05$; n.s. - statistically non-significant difference between vegetation on arable soil and vegetation in the area of medieval ore extraction; ${ }^{*}-$ significant difference $\mathrm{p}=0.05$; ${ }^{* *}-$ significant $^{*}$ difference $\mathrm{p}=0.01$. 
(Partzsch 2011), presents also a significant relation with the habitats of later period of succession (also in areas of medieval ore extraction), as shown in Figure 3.

Woody plants predominate in the areas abandoned be-

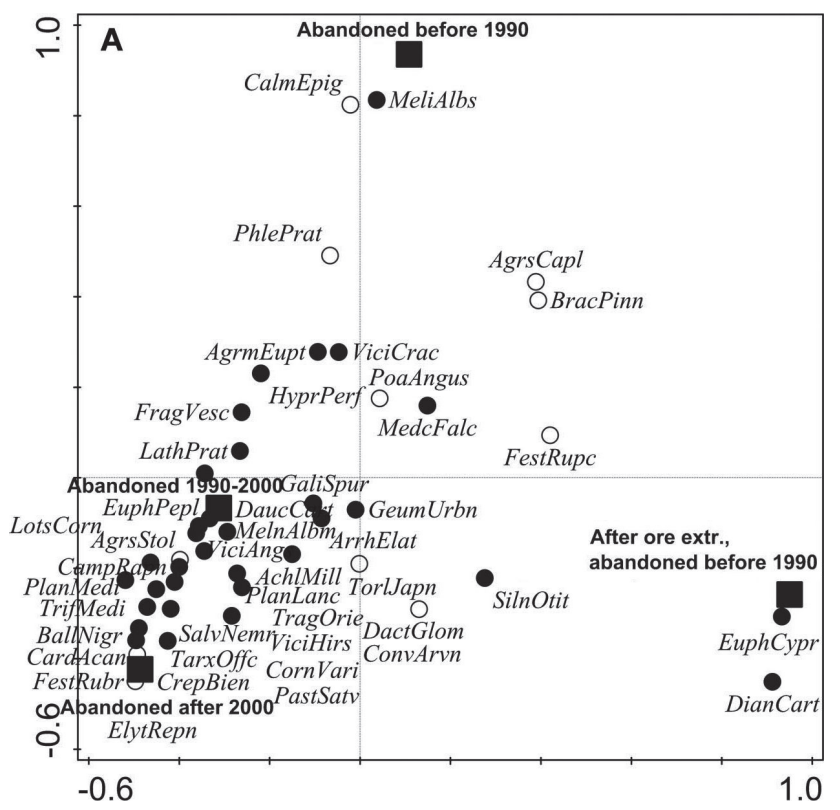

fore 1990 (Figure 3, 4c), including species such as Acer pseudoplatanus, Acer platanoides, Cornus mas, Ligustrum vulgare and Crataegus oxyacantha. The woody plants initially took root under the old planted cherry trees.

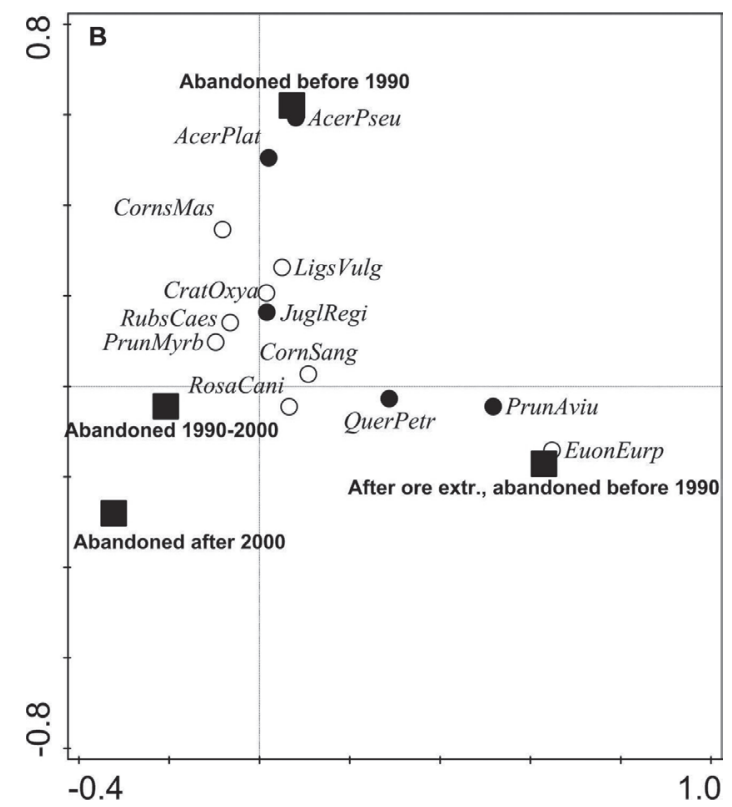

Figure 3: Indirect DCA gradient analysis of plant species (the first two axes capture $30 \%$ data variability) in relation to the length of abandonment and type of habitat. Individual species are indicated with small spots (empty - shrubs and graminoids, black - trees and forbs). Only species occurred in more than 2 plots were plotted. The length of abandonment and type of habitat are indicated with black squares. Species abbreviations are based on four letters for the genus and species (see Appendix). A - Herbs, B - Woody plants.

Slika 3: Indirektna DCA gradientna analiza rastlinskih vrst (prvi dve osi pojasnjujeta 30\% variabilnosti) v odnosu do časa od opustitve rabe in vrsto habitata. Posamezne vrste so prikazane z majhnimi točkami (prazne - grmovnice in trave, črne - drevesa in zeli). Prikazane so samo vrste, ki se pojavljajo vsaj v dveh ploskvah. Obdobje od opustitve gospodarjenja in vrsta habitata sta prikazana s črnimi kvadrati. Okrajšave vrst so prikazane s štirimi črkami za rod in vrsto (glej prilogo). A - zeli, B - lesnate rastline.

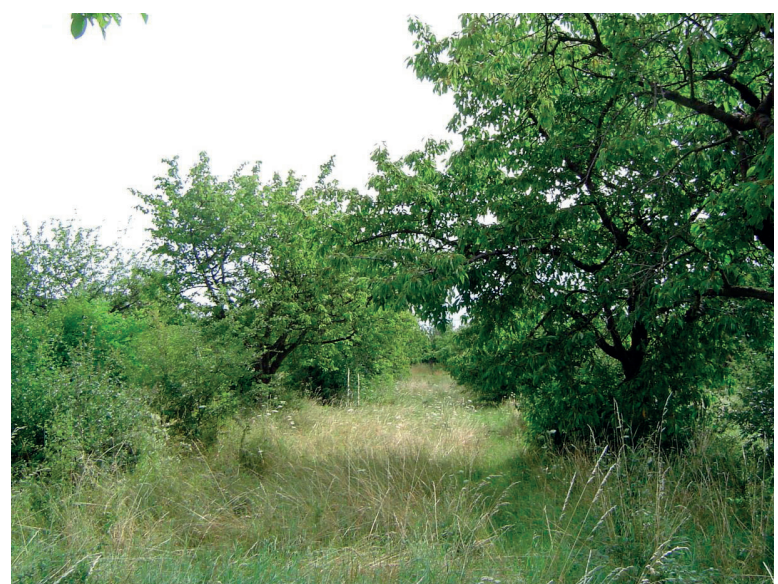

Figure 4a: Tall-trunk cherry orchard in former arable land abandoned after 2000 .

Slika 4a: Visokodebelni češnjev sadovnjak na nekdanjih obdelanih tleh, opuščen po letu 2000 .

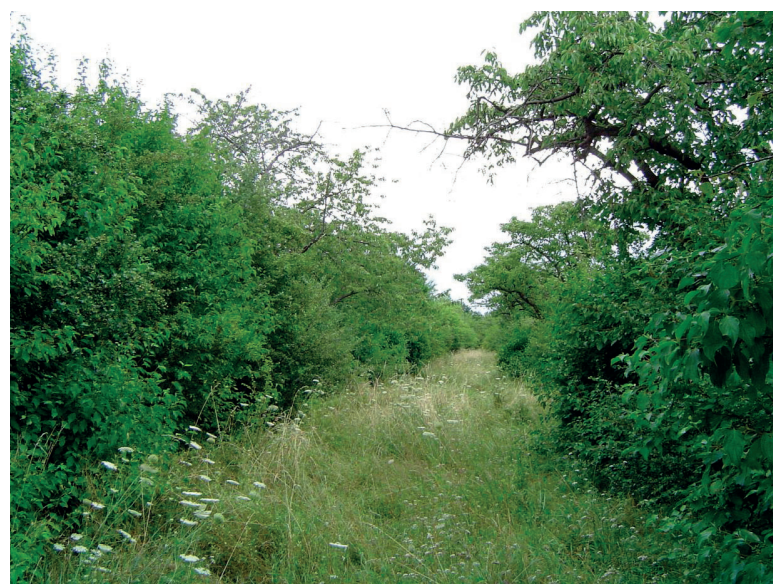

Figure 4b: Tall-trunk cherry orchard in former arable land abandoned during period 1990-2000.

Slika 4b: Visokodebelni češnjev sadovnjak na nekdanjih obdelanih tleh, opuščen v obdobju 1990-2000. 
These results correspond to the conclusion made by Debussche \& Lepart (1992) that the best conditions for the development of tree seedlings with pulpy fruits occur at the edge of large tree crowns. The interplay of seed propagation by birds and a suitable environment for the development of seedlings near woody plants leads to the expansion of shrubs from trees to the grasslands. This tree propagation mechanism has also been reported by Jordano (1994) and Milton et al. (1997).

In the initial period of secondary succession, significantly higher values of species diversity were recorded,

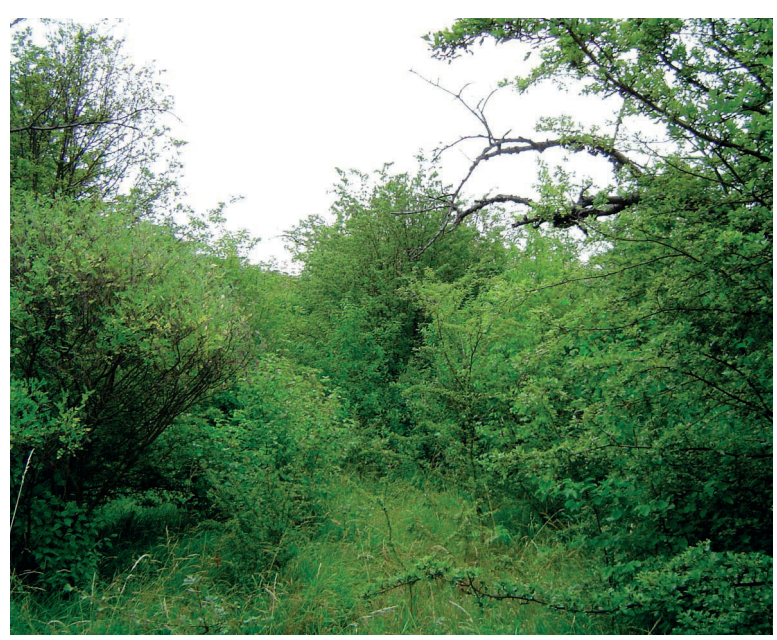

Figure 4c: Tall-trunk cherry orchard in former arable land abandoned before 1990 .

Slika 4c: Visokodebelni češnjev sadovnjak na nekdanjih obdelanih tleh, opuščen pred letom 1990.

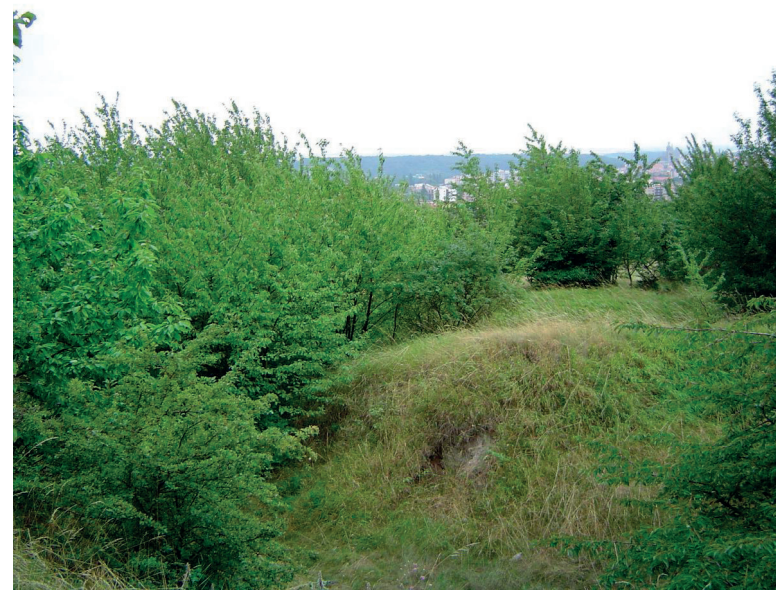

Figure 4d: Tall-trunk cherry orchard in the area of medieval ore extraction abandoned before 1990 .

Slika 4d: Visokodebelni češnjev sadovnjak na območju jalovine srednjeveških rudnikov, opuščen po letu 2000. which was probably due to the increase in the number of woody species and the occurrence of new herb species for which favourable conditions were created. During the next period, however, the values of diversity decreased as a result of the degradation of dry grasslands, which was caused by the growth of bushes. Decreasing species richness in connection with the gradual overgrowth of abandoned orchards was also documented by Milton et al. (1997).

\section{Differences in the composition of vegetation occurring on farmland and in habitats in areas of medieval ore extraction}

The results of the comparison of orchard vegetation produced in former arable lands (Figure 4c) and in areas of medieval ore extraction (Figure 4d) that were abandoned before 1990 are presented in Table 2 and Figure 2 and 3. The total cover of all plant species in the stand was significantly higher in areas of medieval ore extraction. In contrast, the proportion of woody species cover within total vegetation cover was higher in the case of stands growing in former arable land. This situation occurs because the habitats in areas of medieval ore extraction become overgrown less evenly.

The cause of this phenomenon is probably relatively high heterogeneity of terrain morphology and differences in soil substrate quality, which is not favourable for woody plant growth in some places. Open space without shrubs provides a greater opportunity for self-seeding and subsequent growth of woody plants, especially cherry trees (see Figure 3). The greater number of grids that are not covered with woody plants is also related to the fact that in the plots in areas of medieval ore extraction, there is statistically significantly greater cover of the herb layer (Table 2). However, the herb layer is significantly degraded in most of these plots, especially in the undergrowth of trees (specifically, cherry seedlings). This degradation is also associated with a significant decline in species diversity (see Figure 2). Euphorbia cyparissias, Dianthus carthusianorum and Silene ottites presents a significant relation with the habitats in areas of medieval ore extraction, as shown in Figure 3. This can be explained by a considerable proportion of extreme habitat conditions that support development and prosperity of these xerothermic species. 


\section{Conclusions}

The main results of the study of secondary succession in abandoned cherry orchards in the locality Kaňk near Kutná Hora can be summarized as follows:

1) The cover of cherry trees in orchards abandoned before 1990 was approximately $30 \%$ lower than that in orchards abandoned after 2000 .

2) The shrub vegetation in orchards abandoned before 1990 was approximately $2.5 \mathrm{~m}$ higher than that in orchards abandoned after 2000. The cover of the shrubs was higher by approximately $50 \%$.

3) The herb layer covers in orchards abandoned before 1990 was approximately $60 \%$ lower than that in orchards abandoned after 2000 . The height of herbs was approximately $50 \%$ lower.

4) The species diversity in orchards abandoned before 1990 was statistically significantly lower than that in orchards abandoned after 2000 .

5) The share of woody species covers within the total vegetation cover in habitat in areas of medieval ore extraction was approximately $30 \%$ lower than in land used originally for farming.

6) The total cover of all species in habitat in areas of medieval ore extraction was 50\% lower than in land used originally for farming.

7) The vegetation in habitat in areas of medieval ore extraction extends beyond the succession line observed in former arable land.

\section{Acknowledgement}

The research was funded by institutional support from the Silva Tarouca Research Institute for Landscape and Ornamental Gardening (VUKOZ-IP-00027073) and by a long-term research project of the Institute of Botany, Academy of Sciences of the Czech Republic (no. RVO 67985939).

Markéta Šantrůčková (D), https://orcid.org/0000-0003-15198235

Jiří Dostálek DD, https://orcid.org/0000-0003-1214-0409

Tomáš Frantík (D), https://orcid.org/0000-0001-9652-9467

\section{References}

Agnoletti, M. 2014: Rural landscape, nature conservation and culture: some notes on research trends and management approaches from a (southern) European perspective. Landscape and Urban Planning 126: 66-73.

Antrop, M. 2005: Why landscapes of the past are important for the future. Landscape and Urban Planning 70: 21-34.

Benayas, J. M. R., Martins, A., Nicolau, J. M. \& Schulz, J. J. 2007: Abandonment of agricultural land: an overview of drivers and consequences. CAB Reviews: Perspectives in Agriculture, Veterinary Science, Nutrition and Natural Resources 2(057): 1-14.

Benjamin, K., Domon, G. \& Bouchard, A. 2005: Vegetation composition and succession of abandoned farmland: effects of ecological, historical and spatial factors. Landscape Ecology 20: 627-647.

Bič́k, I., Jeleček, L., Kabrda, J., Kupková, L., Lipský, Z., Mareš, P., Šefrna, L., Štych, P. \& Winklerová, J. 2010: Vývoj využití ploch v Česku. Česká geografická společnost, Praha, 251 pp.

Blab, J. 1993: Grundlagen des Biotopschutzes für Tiere. Schriftenreihe für Landschaftspflege und Naturschutz 24: 1-479.

Bürgi, M., Östlund, L. \& Mladenoff, D. J. 2017: Legacy Effects of Human Land Use: Ecosystems as Time-Lagged Systems. Ecosystems 20: 94-103.

Cramer, V. A. \& Hobbs, R. J. (eds.) 2007: Old fields. Dynamics and restoration of abandoned farmland. Island Press, Washington, $352 \mathrm{pp}$.

Debussche, M. \& Lepart, J. 1992: Establishment of woody plants in Mediterranean old fields: opportunity in space and time. Landscape Ecology 6: 133-145.

Debussche, M., Escarré, J. \& Lepart, J. 1982: Ornitochory and plant succession in Mediterranean abandoned orchards. Vegetatio 48: 255-266.

Duchoslav, M. 2009: Flóra a vegetace přírodní památky Chraštická stráň na Chrudimsku. Východočeský sborník prrírodovědný: Práce a studie 16: 111-132.

Forejt, M., Skaloš, J., Pereponova, A., Plieninger, T., Vojta, J. \& Šantrůčková, M. 2017: Changes and continuity of wood-pastures in the lowland landscape in Czechia. Applied Geography 79: 235-244.

Heubes, J., Retzer, V., Schmidtlein, S. \& Beierkuhnlein, C. 2011: Historical land use explains current distribution of calcareous grassland species. Folia Geobotanica 46: 1-16.

Horák, J. \& Hejcman, M. 2013: Use of Trace Elements from Historical Mining for Alluvial Sediment Dating. Soil and Water Research 8(2): 77-86.

Horák, J. \& Hejcman, M. 2016a: 800 years of mining and smelting in Kutná Hora region (the Czech Republic) - spatial and multivariate meta-analysis of contamination studies. Journal of Soils and Sediments 16(5): 1584-1598.

Horák, J. \& Hejcman, M. 2016b: Contamination Characteristics of the Confluence of Polluted and Unpolluted Rivers - Range and Spatial Distribution of Contaminants of a Significant Mining Centre (Kutná Hora, Czech Republic). Soil and Water Research 11(4): 235-243. 
Horák, J., Peltanová, A., Podavková, A., Šafářová, L., Bogusch, P., Romportl, D. \& Zasadil, P. 2013: Biodiversity responses to land use in traditional fruit orchards of a rural agricultural landscape. Agriculture, Ecosystems and Environment 178: 71-77.

Horák, J. \& Šafárová, L. 2010: Výskyt saranče vrzavé (Psophus stridulus L. - Orthoptera: Acrididae) v podhủří Orlických hor s poznámkami k výskytu v Pardubickém kraji. Acta Musei Richnoviensis Sect. Nat. 17(1): $10-14$

Janeček, V., Rada, P., Rom, J. \& Horák, J. (2019): Rural agroforestry artifacts in a city: determinants of spatiotemporally continuous fruit orchards in an urban area. Urban Forestry \& Urban Greening 41: $33-38$.

Jensen, C., Vorren, K. D., Eilertsen, S. M. \& Samuelsen, R. 2001: Successionary stages of formerly cultivated grassland in northern Norway, abandoned for 10, 20 and 35 years. Nordic Journal of Botany 21(3): 305-320.

Jordano, P. 1994: Spatial and temporal variation variation in the avianfrugivore assemblage of Prunus mahaleb: patterns and consequences. Oikos 71: 479-491.

Kajtoch, L. 2017: The importance of traditional orchards for breeding birds: The preliminary study on Central European example. Acta Oecologica 78: 5360

Kay, S., Crous-Duran, J., García de Jalón, S., Graves, A., Palma, J. H. N., Roces-Díaz, J. V., Szerencsits, E., Weibel, R. \& Herzog, F. 2018: Landscape-scale modelling of agroforestry ecosystems services in Swiss orchards: a methodological approach. Landscape Ecology 33: 1633-1644.

Kubát, K., Hrouda, L., Chrtek, J. jun., Kaplan, Z., Kirschner, J. \& Štěpánek, J. (eds.) 2002: Klíč ke květeně Ceské republiky. Academia, Praha, 928 pp.

Lange, S. 1993: Die Bedeutung des Biotops Streuobstwiesen aus der Sicht des Arten- und Biotopschutzes sowie der Landschaftsplanung am Beispiel des Stadtgebietes Halle/Saale. Berich. Landesamt für Umweltschutz Sachsen-Anhalt 13: 32-36.

Maděra, P. et al. 2014: Czech villages in Romanian Banat: landscape, nature, and culture. Mendel University, Brno, 348 pp.

McCollin, D., Moore, L. \& Sparks, T. 2000: The flora of a cultural landscape: environmental determinants of change revealed using archival sources. Biological Conservation 92(2): 249-263.

Mikyška, R. et al. 1968: Geobotanická mapa ČSSR 1. České země. Academia, Praha, 204 pp.

Mikyška, R. et al. 1972: Geobotanická mapa ČSSR. 1. České země. Academia, Praha, mapová část.

Milton, S. J., Dean, W. R. J. \& Klotz, S. 1997: Thicket formation in abandoned fruit orchards: processes and implications for the conservation of semi-dry grasslands in Central Germany. Biodiversity and Conservation 6: 275-290.
Neuhäuslová, Z.et al. 2001: Mapa potenciální přirozené vegetace České republiky. Academia, Praha, 341 pp.

Osbornová, J., Kovárová, M., Lepš, J. \& Prach, K. (eds.) 1990: Succession in abandoned fields. Studies in Central Bohemia, Czechoslovakia. Kluwer Academic Publishers, Dordrecht, 168 pp.

Partzsch, M. (2011): Does land use change affect the interactions between two dry grasslands species? Flora 206: 550-558.

Pielou, E. C. 1966: The measurement of diversity in different types of biological collections. Journal of Theoretical Biology 13: 131-144.

Quitt, E. 1971: Klimatické oblasti Československa. Studia geographica 16: $1-170$.

Reck, H. R. 1993: Spezieller Artenschutz und Biotopschutz: Zielarten als Naturschutzstrategie und ihre Bedeutung als Indikatoren bei der Beurteilung der Gefährdung von Biotopen. Schriftenreihe für Landschaftspllege und Naturschutz 38: 159-178.

Skaloš, J., Weber, M., Lipský, Z., Trpáková, I., Šantrůčková, M., Uhlírová, L. \& Kukla, P. 2011: Using old military survey maps and orthophotograph maps to analyse long-term land cover changes - Case study (Czech Republic). Applied Geography 31: 426-438.

Šantrůčková, M., Dostálek, J. \& Demková, K. 2015: Assessing long-term spatial changes of natural habitats using old maps and archival sources: a case study from Central Europe. Biodiversity and Conservation 24: 1899-1916.

Špulerová, J., Piscová, V., Gerhátová, K., Bača, A., Kalivoda, H. \& Kanka, R. 2015: Orchards as traces of traditional agricultural landscape in Slovakia. Agriculture, Ecosystems and Environment 199: 67-76.

Špulerová, J., Petrovič, F., Mederly, P., Mojses, M. \& Izakovičová, Z. 2018: Contribution of Traditional Farming to Ecosystem Services Provision: Case Studies from Slovakia. Land 7(2): 1-24.

Ter Braak, C. J. F. \& Šmilauer, P. 2002: CANOCO Reference Manual and CanoDraw for Windows User's Guide: Software for Canonical Community Ordination (version 4.5.). Microcomputer Power, Ithaca, New York, 500 pp.

Tomášek, M. 2000: Půdy České republiky. Český geologický ústav, Praha, $67 \mathrm{pp}$.

Ustaoglu, E. \& Collier, M. J. 2018: Farmland abandonment in Europe: an overview of drivers consequences, and assessment of the sustainability implications. Environmental Reviews 26(4): 396-416.

Vačkář, D., Chobot, K. \& Orlitová, E. 2012: Spatial relationship between human population density, land use intensity and biodiversity in the Czech Republic. Landscape Ecology 27(9): 1279-1290.

Verburg, P. H. \& Overmars, K. P. 2009: Combining top-down and bottom-up dynamics in land use modelling: exploring the future of abandoned farmlands in Europe with the Dyna-CLUE model. Landscape Ecology 24: 1167-1181. 


\section{Old maps}

Military maps of the 1st, 2nd and 3rd Military Survey, Austrian State Archive/Military Archive, Vienna; Geoinformatics Laboratory, University of J. E. Purkyně, Ministry of the Environment of the Czech Republic (http:// oldmaps.geolab.cz), Ministry of the Environment of the Czech Republic 2003, deposited at: VÚKOZ, v.v.i.; Map Collection of Charles University in Prague, Faculty of Science.

Stable cadastral maps, State Administration of Land Surveying and Cadastre

\section{Appendix}

List of species found at the investigated plots

Acer campestre
Acer platanoides
Acer pseudoplatanus
Agrimonia eupatoria
Agrostis capillaris
Agrostis stolonifera
Achillea millefolium
Anthericum ramosum
Arrhenatherum elatius
Asparagus officinalis
Ballota nigra
Brachypodium pinnatum
Calamagrostis epigeos
Campanula rapunculoides
Carduus acanthoides
Carex hirta
Carex muricata
Carex sylvatica
Centaurea jacea
Cichorium intybus
Cirsium arvense
Cirsium eriophorum
Cirsium vulgare
Concolvulus arvensis
Cornus mas

Heracleum sphodyllium

Hieracium pilosella

Hieracium sabaudum

Hypericum perforatum

Juglans regia

Knautia arvensis

Koeleria macrantha

Lactuca serriola

Lamium album

Lathyrus pratensis

Ligustrum vulgare

Lotus corniculatus

Malus domestica

Medicago falcata

Medicago lupulina

Melandrium album

Melilotus albus

Mentha piperita

Pastinaca sativa

Phleum pratense

Plantago lanceolata

Plantago media

Poa angustifolia

Potentilla argentea

Potentilla intermedia

\section{Aerial photographs}

State Administration of Land Surveying and Cadastre and Military Geographic and Hydrometeorologic Office Dobruška

$\begin{array}{ll}\text { Cornus sanguinea } & \text { Potentilla reptans } \\ \text { Coronilla varia } & \text { Prunus avium } \\ \text { Crataegus oxyacantha } & \text { Prunus mahaleb } \\ \text { Crepis biennis } & \text { Prunus myrobalana } \\ \text { Dactylis glomerata } & \text { Prunus sp. } \\ \text { Daucus carota } & \text { Prunus spinosa } \\ \text { Dianthus carhusianorum } & \text { Quercus petraea } \\ \text { Echinops sphaerocephalus } & \text { Ribes rubrum } \\ \text { Echium vulgare } & \text { Robinia pseudoacacia } \\ \text { Elytrigia intermedia } & \text { Rosa canina } \\ \text { Elytrigia repens } & \text { Rubus caesius } \\ \text { Eryngium campestre } & \text { Rumex acetosella } \\ \text { Euonymus europaea } & \text { Salvia nemorosa } \\ \text { Euphorbia cyparissias } & \text { Sambucus nigra } \\ \text { Euphorbia peplus } & \text { Scabiosa ochroleuca } \\ \text { Festuca rubra } & \text { Silene otites } \\ \text { Festuca rupicola } & \text { Solidago canadensis } \\ \text { Fragaria vesca } & \text { Taraxacum offcinale } \\ \text { Fragaria viridis } & \text { Thymus pullegioides } \\ \text { Fraxinus excelsior } & \text { Torilis japonica } \\ \text { Galium molugo } & \text { Tragopogon orientalis } \\ \text { Galium spurium } & \text { Trifolium medium } \\ \text { Geranium pratense } & \text { Vicia angustifolia } \\ \text { Geum urbanum } & \text { Vicia cracca } \\ \text { Hedera helix } & \text { Vicia hirsuta } \\ & \end{array}$

